\title{
SElfCARE In TyPe I Diabetes With Continuous Glucose Monitoring
}

\author{
Elham Nazari*1(D, Somaye Nazari² ${ }^{(1)}$
}

${ }^{1} \mathrm{PhD}$ Student in Medical Informatics, Mashhad University of Medical Science, Mashhad, Iran. ${ }^{2}$ Master Student in toxicology, Mashhad University of Medical Science, Mashhad, Iran.

\begin{tabular}{|c|c|}
\hline Article Info & A B S T RA C T \\
\hline $\begin{array}{l}\text { Article type: } \\
\text { Research }\end{array}$ & \multirow{2}{*}{$\begin{array}{l}\text { Introduction: } \\
\text { Number of diabetic patients are increasing. If the blood glucose not } \\
\text { controlled in diabetics, patients will face with complications. Self-care is } \\
\text { important to control the blood glucose of diabetic patients and prevention } \\
\text { of complications such as neurological complications, heart, eye disease, } \\
\text { amputations and so on. Therefore the aim of this study is to identify the } \\
\text { effects of Continuous Glucose Monitoring (CGM) on the blood glucose } \\
\text { control in type I diabetes. }\end{array}$} \\
\hline $\begin{array}{l}\text { Article History: } \\
\text { Received: } 2018-12-14 \\
\text { Revised: } 2019-01-18 \\
\text { Accepted: 2019-01-29 }\end{array}$ & \\
\hline $\begin{array}{l}\text { * Corresponding author: } \\
\text { Elham Nazari } \\
\text { PhD Student in Medical Informatics, } \\
\text { Mashhad University of Medical } \\
\text { Science, Mashhad, Iran. } \\
\text { Email: Nazarie951@mums.ac.ir }\end{array}$ & $\begin{array}{l}\text { Material and Methods: } \\
\text { The study was done on } 20 \text { patients chosen from an online data set available } \\
\text { in http://www.jaeb-diabetes.net/. These patients used CGM to test blood } \\
\text { glucose and the result of three month test was measured. To analyze the } \\
\text { data, the software SPSS } 21 \text {, independent Mann- Whitney test was used. }\end{array}$ \\
\hline & $\begin{array}{l}\text { Results: } \\
\text { The results showed that blood glucose in patients of the experimental group } \\
\text { reduced significantly rather than patient of the control group in the second } \\
\text { and third month. Also, HbA1C of the patients has reduced. }\end{array}$ \\
\hline & $\begin{array}{l}\text { Conclusion: } \\
\text { The CGM has an effective role in controlling blood glucose and prevention of } \\
\text { complications. Therefore it is recommended that educational programs on } \\
\text { the use of monitoring blood glucose, such as CGM as a requirement to be } \\
\text { developed. }\end{array}$ \\
\hline & $\begin{array}{l}\text { Keywords: } \\
\text { Self-care, Type I diabetes, Continuous Glucose Monitoring }\end{array}$ \\
\hline
\end{tabular}

How to cite this paper

Nazari E, Nazari S. Selfcare in Type I Diabetes with Continuous Glucose Monitoring. Front Health Inform. 2019; 8(1): e5. DOI: $\underline{10.30699 / f h i . v 8 i 1.169}$

\section{INTRODUCTION}

Diabetes is a chronic immedicable but controllable, and is known as the most important epidemic of country and future disease [1]. It's the fifth cause of death [2]. According to the last statistics, 387 Millions are diabetics (patients) in the world []ㅡ. Every year about 5 Million die because of the diabetes in the world. The prevention and treatment cost of diabetes and its complication, is more over than 376 billion dollars over the world and related costs and its Complication is different from 2.5 to 15 percent of the world yearly healthy budget. Diabetes is known the most expensive glandular disease in the world [4]. Pancreas of these patients, don't secrete insulin hormone to consume the existent glucose in the food by the cells []․ This circumstance causes patient blood glucose increase []. Therefore, these patients by receiving continuous insulin must put the blood glucose in a normal range and for continuous blood glucose stability and prevention of its numerous complication like kidney, neural, heart disease, eye complication and amputation, they can use of devices such as Glucometer and Continuous Glucose monitoring (CGM) [-ㅜ]. On the basis of the evaluation, the most important factor causes death in patients is no carrying out the self-care [1ㅣ] $]$. Self-care is a process that a patient should do daily to control the disease adequately. Suitable diet, following the medicinal treatment, Blood glucose control, activity level and feet observation treatment, are the most important self-care activities of the diabetic patient self-care can be effective in evaluating the clinical Cases in the hospitals and improvement of life [투 $\underline{11}$ 13]. Among the useful devices is CGM use for continuous blood glucose stability that is known as 
CGMS or continuous Glucose Monitoring system in Iran and its power to blood glucose stability has been approved in the scientific contexts [ $\underline{7}-\underline{9}]$. The results of this research can be used as a base for later researches such as evaluating the usage level of different instruction programs for diabetes patient self-care in using of controlling devices. So, considering the importance of diabetes patient selfcare, this study was done with the purpose of identifying effect of using the CGM to control the blood glucose in existent patients in online data bases.

\section{MATERIAL AND METHODS}

Research community in this study included choosing 20 existent patients among 491 one type diabetes in the age range of 8-50 of the data base who recorded their blood glucose in questionnaires designed for this purpose, via CGM for 26 weeks and results of one-two and three months was considered for the present study. Among the existent patients, HbA1C lower than one considered as the control group and ten people were chosen with the same situation of age and gender from both of the groups. The used database contains data that resulted from an accidental clinical test to evaluate the usage of CGM for disease stability and children diabetes management and this data is available in http://www.jaeb-diabetes.net/ .Evaluation and validation of the questionnaire content and structure also its reliability, is approved by Juvenile Diabetes Research Foundation of America. To analysis the data, software SPSS21 and Mann- Whitney test (with respect of non-normality of data in two group) is used.

\section{RESULTS}

The groups of experimental and control was chosen of the same genders and ages. Table 1 shows the information related to self-care about measuring blood glucose among two considered groups.

Table1: Significant level of the evaluated variable

\begin{tabular}{|l|c|c|c|}
\hline & $\begin{array}{l}\text { Experiment } \\
\text { and control } \\
\text { after one } \\
\text { month }\end{array}$ & $\begin{array}{l}\text { Experiment } \\
\text { and control } \\
\text { after two } \\
\text { month }\end{array}$ & $\begin{array}{l}\text { Experiment } \\
\text { and control } \\
\text { after three } \\
\text { month }\end{array}$ \\
\hline $\begin{array}{l}\text { Blood } \\
\text { Glucose }\end{array}$ & 0.751 & 0.001 & 0.001 \\
\hline
\end{tabular}

According to the Table 1, there weren't any significant differences between experimental and control group at the first month, but when comparing the averages of these groups in the second and third month, there was a remarkable difference. Therefore the control process from the first month is done well. It seems that such improvement is because of adjustment and learning by CGM in blood glucose control.

Table 2: Average and standard deviation of blood glucose in experimental and control groups

\begin{tabular}{|l|l|l|}
\hline & $\begin{array}{l}\text { Average } \\
(\mathrm{mg} / \mathrm{dL})\end{array}$ & $\begin{array}{l}\text { Standard } \\
\text { deviation } \\
(\mathrm{mg} / \mathrm{dL})\end{array}$ \\
\hline Experiment after one month & 169.28 & 57.282 \\
\hline Control after one month & 170.345 & 70.792 \\
\hline $\begin{array}{l}\text { Experiment after two } \\
\text { month }\end{array}$ & 165.144 & 57.674 \\
\hline Control after two month & 180.646 & 79.981 \\
\hline $\begin{array}{l}\text { Experiment after three } \\
\text { month }\end{array}$ & 160.956 & 59.208 \\
\hline Control after three month & 177.637 & 80.573 \\
\hline
\end{tabular}

The average of blood glucose in experimental group patients, because of using the CGM in the second and third month, reduced rather than the control group, and this circumstance is because of control process of blood glucose with CGM. Chart below, shows the blood glucose average in first, second and third month of evaluation among two groups of experimental and control.

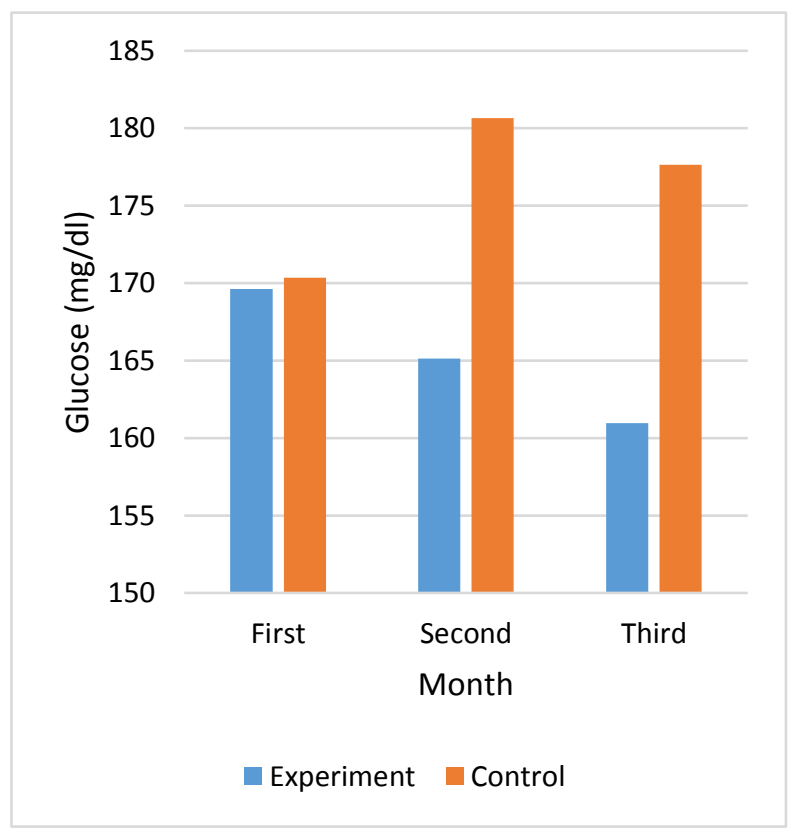

Fig 1: The average of blood glucose in the experimental and control group of one, two and 3 month.

\section{DISCUSSION}

The purpose of this study was the difference evaluation in self-care condition of patients who used CGM to control the blood glucose. Then results obtained from the evaluation in the group of experimental and control was compared statistically. The results showed that blood glucose in the group of experimental reduced in the second and third month of evaluation rather than group of control and it showed a significant differences. This difference was as a result of continuous blood glucose monitoring by CGM, that 
in this device when blood glucose is high, an alarm is gave and it makes patient able to manage the disease continuously. The present study is coordinated with similar studies, hence that it makes the patient able to manage the blood glucose control, after using CGM for a long time and The HbA1C of the patient is decreased. Present study evaluated two group as control group and experimental group with HbA1C higher and lower than 7 percent, that both of them were using CGM and it's done with the purpose of evaluating the self-care ability of patient. To evaluate the self-care by using of CGM in different month and not only after months of doing the experiment. For example, in the study that was done by Longendometal, about 2883 one type diabetes for 3 to 18 months Among the patients who used glucometer or CGM to control the blood glucose, there was a better improvement in group CGM rather than group of Glucometer [14] Also, in the study that was done by chase et al in 2010 about 80 patients, in the age range of 8-17 and lasted for 12 months, patients used CGM to control their blood glucose and as a result of using CGM they observed some improvement in HbA1C level and blood glucose reduction [14]. Also, in the study done by Battelino et al in 2011, the effect of CGM on reduction of blood glucose and $\mathrm{HbA} 1 \mathrm{C}$ reduction of 120 patients (type I diabetes) evaluated and approved [14]. Also, based on the study which has been done in 2009 , about 83 patients with the ages more than 25 and suffering from one type diabetes and the study lasted for 6 month, a remarkable improvement in $\mathrm{HbA1C}$ resulted from using CGM. In the other study in 2004 about 124 patients suffering from one type diabetes, HbA1C of the patient that used CGM to control the blood glucose got better [14]. Also, in a study that was done by Teenage diabetes association, 322 patients who used CGM and Glucometer to manage their illness, were evaluated, that it showed a significant differences in the age groups of more than 25 years old. [15] Present study isn't inconsistent to none of other similar studies, in addition an evaluation has been done separately, which lasted for 3 month. Therefore, it's necessary that providers, by providing needed instructions, help to patients for self-care and prevent from numerous complications. The results of the study that was done by Solhi and co-workers, were positive about the effective role of performing instruction program on increasing the of performing instruction program on increasing the self-care level in patients, and it seems that performing such programs can be effective in treatment and prevention of diabetes complications [ $\underline{16}-\underline{18}]$.

\section{CONCLUSION}

Necessary instructions about doing self-care activities specially by the nurses and nutrition experts and observation providers, is the most important elements of optimized from of self-care process, and in the other hand, success in the self-care programs needs to increase the knowledge of the patients and their families about controlling the illness and using the devices such as CGM. These factors facilitate the self-care process [19].

\section{ACKNOWLEDGEMENT}

At the end, we appreciate guidance of Dr Romans Hovorka who is a member of children diabetes modeling group from Cambridge University, for using of the online dataset.

\section{AUTHOR'S CONTRIBUTION}

All the authors approved the final version of the manuscript.

\section{CONFLICTS OF INTEREST}

The authors declare no conflicts of interest regarding the publication of this study.

\section{FINANCIAL DISCLOSURE}

No financial interests related to the material of this manuscript have been declared.

\section{REFERENCES}

1. Facchinetti A, Sparacino G, Cobelli C. Signal processing algorithms implementing the "Smart Sensor" concept to improve continuous glucose monitoring in diabetes. J Diabetes Sci Technol. 2013; 7(5): 1308-18. PMID: 24124959 DOI: $10.1177 / 193229681300700522$ [PubMed]

2. International Diabetes Federation. Diabete in Iran. [Internet] 2017. [cited: 15 Oct 2018]. Available from: https://www.idf.org/diabetesatlas/update.

3. Koo M, Lee MH, Chang Y, Huang CF, Chen SC, Yeh YC. Factors associated with self- care behaviors in middle aged adults and elderly with diabetes mellitus. $\mathrm{Hu} \mathrm{Li}$ Za Zhi. 2011; 58(5): 43-52. PMID: 22024804 [PubMed]

4. Abu-Rmileh AHA. Control and modeling techniques in biomedical engineering: The artificial pancreas for patients with type I diabetes. [PhD thesis] Universitat de Girona; Departament d'Economia. 2013.

5. Stone M, Camosso-Stefinovic J, Wilkinson J, De Lusignan S, Hattersley A, Khunti K. Incorrect and incomplete coding and classification of diabetes: A systematic review. Diabet Med. 2010; 27(5): 491-7. PMID: $\quad 20536944 \quad$ DOI: $10.1111 /$ j.14645491.2009.02920.x [PubMed]

6. Shrivastava SR, Shrivastava PS, Ramasamy J. Role of self-care in management of diabetes mellitus. J Diabetes Metab Disord. 2013; 12(1): 14-8. PMID: 23497559 DOI: 10.1186/2251-6581-12-14 [PubMed]

7. Keenan DB, Grosman B, Clark HW, Roy A, Weinzimer $\mathrm{SA}$, Shah RV, et al. Continuous glucose monitoring considerations for the development of a closed-loop artificial pancreas system. J Diabetes Sci Technol. 2011; 5(6): 1327-36. PMID: 22226249 DOI: $10.1177 / 193229681100500603$ [PubMed]

8. Vashist SK. Continuous glucose monitoring systems: A review. Diagnostics. 2013; 3(4): 385-412. PMID: $26824930 \quad$ DOI: $\quad 10.3390 /$ diagnostics3040385 [PubMed]

9. Eigner G, Sas PI, Kovács L, editors. Continuous glucose monitoring systems in the service of artificial pancreas. International Symposium on Applied Computational Intelligence and Informatics, IEEE; 2014.

10. Landim CA, Zanetti ML, Santos MA, Andrade TA, Teixeira CR. Self-care competence in the case of Brazilian patients with diabetes mellitus in a 
multiprofessional educational programme. J ClinNurs. 2011; 20(23-24): 3394-403. PMID: 22008019 DOI: 10.1111/j.1365-2702.2011.03883.x [PubMed]

11. Baquedano IR, Dos Santos MA, Martins TA, Zanetti ML. Self-care of patients with diabetes mellitus cared for at an emergency service in Mexico. Rev Lat Am Enfermagem. 2010; 18(6): 1195-202. PMID: 21340286 [PubMed]

12. Jordan DN, Jordan J. Self-care behaviors of Filipino American adult with type 2 diabetes mellitus. J Diabetes Complications. 2010; 24(4): 250-8. PMID: 19615920 DOI: 10.1016/j.jdiacomp.2009.03.006 [PubMed]

13. American Daiabets Association. Standards of medical care in diabetes: 2017 Abridged for primary care providers. Clinical Diabetes. 2017; 35(1): 5-26.

14. UnitedHealthcare Commercial Medical Policy. Continuous glucose monitoring and insulin delivery for managig diabetes (Effective 04/22/2015). United Helthcare Services; 2015.

15. Huang ES, O'Grady M, Basu A, Winn A, John P, Lee J, et al. The cost-effectiveness of continuous glucose monitoring in type I diabetes. Diabetes Care. 2010; 33(6): 1269-74. PMID: 20332354 DOI: 10.2337/dc09-2042 [ubMed]

16. Jalilian F, Zinat Motlagh F, Solhi M. Effectiveness of education program on increasing self management among patients with type II diabetes. Journal of Ilam University of Medical Sciences. 2012; 20 (1): 26-34.

17. Jaglal SB, Haroun VA, Salbach NM, Hawker G, Voth J, Lou $\mathrm{W}$, et al. Increasing access to chronic disease selfmanagement programs in rural and remote communities using telehealth. Telemed J E Health. 2013; 19(6): 467-73. PMID: 23570277 DOI: 10.1089/tmj.2012.0197 [PubMed]

18. Vogelmeier CF, Criner GJ, Martinez FJ, Anzueto A, Barnes PJ, Bourbeau J, et al. Global strategy for the diagnosis, management, and prevention of chronic obstructive lung disease 2017 report: GOLD executive summary. Am J Respir Crit Care Med. 2017; 195(5): 557-82. $\quad$ PMID: 28128970 DOI: 10.1164/rccm.201701-0218PP [PubMed]

19. Farahani MA, Mohammadi E, Ahmadi F, Mohammadi N. Factors influencing the patient education: A qualitative research. Iran J Nurs Midwifery Res. 2013; 18(2): 133-9. PMID: 23983743 [PubMed] 